\title{
Penerapan Model Penemuan Terbimbing Untuk Meningkatkan Pemahaman Matematis Siswa Kelas F4 SMAN 5 Malang Pada Materi Turunan
}

\author{
${ }^{1}$ Iska Agustina, ${ }^{2}$ Abd Qohar \\ Jurusan Matematika, Universitas Negeri Malang, Indonesia
}

Email: ${ }^{1}$ iska.1703118@ students.um.ac.id, ${ }^{2}$ abd.qohar.fmipa@um.ac.id

\section{Tersedia Online di}

http://www.jurnal.unublitar.ac.id/i ndex.php/briliant

\section{Sejarah Artikel}

Diterima pada 29 April 2020

Disetujui pada 12 Mei 2020

Dipublikasikan pada 30 Mei 2020

Hal. 283-291

\section{Kata Kunci:}

Pemahaman matematis; penemuan terbimbing; turunan fungsi

\section{DOI:}

http://dx.doi.org/10.28926/briliant. v3i4.466

\begin{abstract}
Abstrak: Pemahaman matematis adalah kemampuan yang penting untuk dimiliki siswa. Namun demikian pemahaman matematis siswa secara umum masih rendah. Artikel ini berisi tentang hasil penelitian tindakan kelas yang bertujuan untuk meningkatkan pemahaman matematis siswa. Subyek penelitian ini adalah siswa kelas XI MIPA F4 SMAN 5 Malang. Penelitian ini dilakukan dalam 2 siklus dengan 4 pertemuan tiap siklus. Hasil penelitian menunjukkan bahwa penerapan model penemuan terbimbing dapat meningkatkan pemahaman matematis siswa pada materi turunan. Hasil dari tes pemahaman matematis siswa mengalami peningkatan dari rata-rata hasil tes pada siklus I yaitu 70.1 menjadi 85.54 pada siklus II. Dari penelitian ini disarankan untuk para guru untuk memberikan pengetahuan prasyarat untuk materi yang akan diajarkan supaya siswa bisa memprediksi apa yang akan dipelajari. Selain itu
\end{abstract} guru disarankan memberi scaffolding secara khusus kepada siswa supaya siswa lebih aktif dalam berdiskusi dan dapat membangun pengetahuannya sendiri.

\section{PENDAHULUAN}

Pemahaman dapat diartikan sebagai kemampuan seseorang untuk mengetahui sesuatu itu benar atau salah. Pemahaman matematis adalah kemampuan yang diperlukan siswa agar dapat mengikuti pembelajaran matematika dengan baik. Kilpatrik, Swafford, \& Findell (2001) mendukung hal ini dengan menyebutkan bahwa pemahaman konsep matematis perlu dikuasai setiap orang yang belajar matematika. Skemp (1976) menggolongkan pemahaman matematis menjadi dua yaitu pemahaman instrumental dan relasional. Pemahaman instrumental adalah kemampuan menerapkan prosedur matematis dalam menyelesaikan masalah tanpa mengetahui alasan penggunaan prosedur tersebut. Sedangkan, pemahaman relasional adalah kemampuan untuk menerapkan prosedur matematis dan mengetahui alasan prosedur itu digunakan. Hiebert (dalam Even \& Tirosh, 2002) menyatakan yang dimaksud pengetahuan prosedural merupakan pemahaman instrumental, dan pemahaman konseptual merupakan pemahaman relasional seperti yang dimaksud oleh Skemp. Selanjutnya Even \& Tirosh (2002) mengemukakan bahwa Hiebert tidak memberi batas yang jelas antara dua kemampuan tersebut, sedangkan Skemp memberi batas yang jelas. Bloom (1956) merumuskan indikator pemahaman menjadi 3 yaitu (1) translation yaitu kemampuan menerjemahkan dari 
abstrak menjadi model matematis; (2) interpretation yaitu kemampuan menafsirkan; (3) extrapolation yaitu kemampuan menyimpulkan dari apa yang diketahui. Sedangkan Anderson \& Krathwohl (2001) menyatakan bahwa pemahaman ada 7 tingkatan, yaitu: Interpreting, Exemplifying, Summarizing, Inferring, Comparing dan Explaining.

Pemahaman matematis siswa pada umumnya masih rendah. Rendahnya pemahaman matematis siswa ditemukan oleh Minarni, Napitupulu, \& Husein (2016). Berdasarkan penelitian tersebut, pemahaman dan representasi siswa rendah berdasarkan hasil tes esai. Kurangnya pemahaman matematis salah satunya dapat dilihat dengan adanya kesalahan dalam menyelesaikan masalah matematika. Hal ini didukung oleh studi pendahuluan yang peneliti lakukan di SMAN 5 Malang. Hasil observasi menunjukkan bahwa siswa memiliki pemahaman matematis yang kurang yang ditandai dengan adanya kesalahan dalam menyelesaikan masalah matematika. Salah satu siswa melakukan kesalahan dalam menyelesaikan soal aplikasi barisan dan deret yaitu soal yang berkaitan dengan pertumbuhan. Gambar 1 menunjukkan kesalahan tersebut.

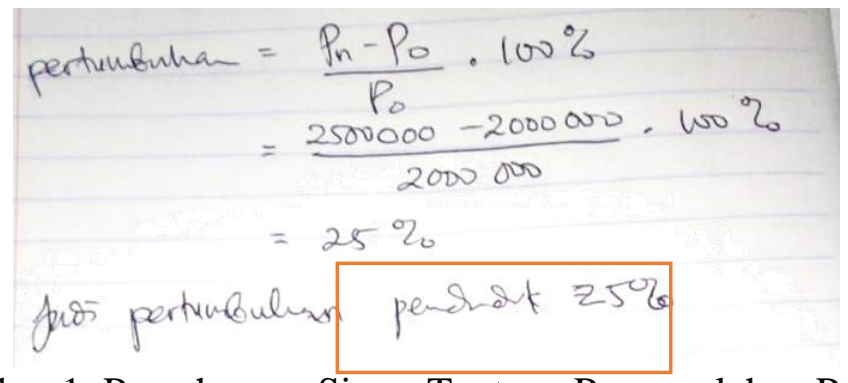

Gambar 1. Pemahaman Siswa Tentang Permasalahan Pertumbuhan

Pada Gambar 1 terdapat penyelesaian masalah yang berkaitan dengan materi pertumbuhan yang merupakan aplikasi barisan dan deret. Dari tulisan tersebut dapat dilihat bahwa terdapat indikasi bahwa siswa paham peningkatan yang dialami penduduk selama 10 tahun namun siswa tidak menghubungkannya dengan masalah pertumbuhan yang merupakan barisan geometri. Terdapat indikasi bahwa siswa belum mengetahui bahwa yang ditanyakan adalah tingkat pertumbuhan penduduk per tahun. Dari penyelesaian tersebut dapat diketahui bahwa siswa belum memahami soal yang diberikan. Pemahaman siswa masih terbatas pada translation.

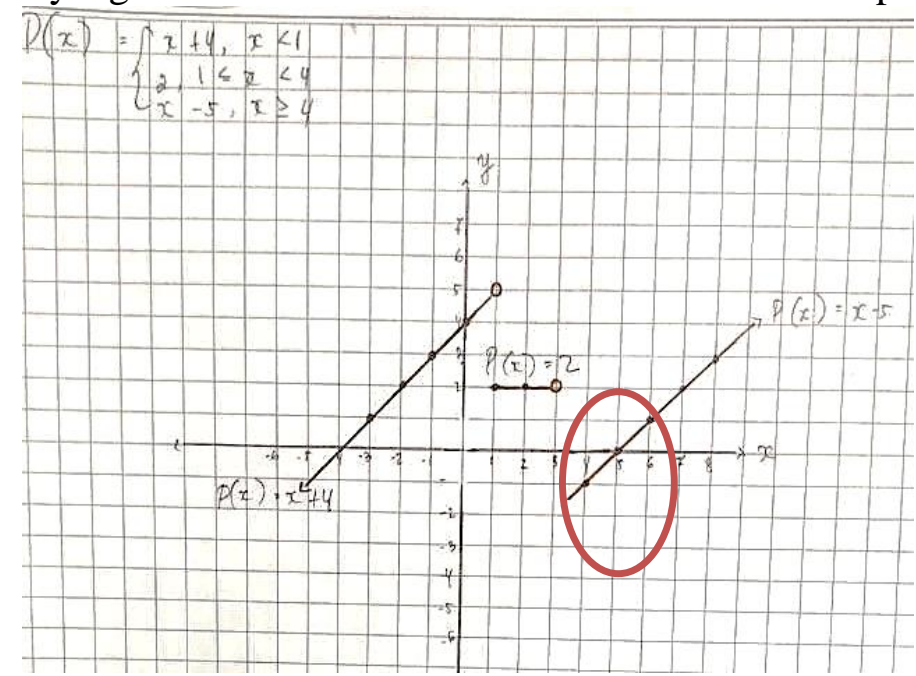

Gambar 2. Pemahaman siswa tentang Grafik Fungsi

284 BRILIANT: Jurnal Riset dan Konseptual Volume 5 Nomor 2, Mei 2020 
Pada Gambar 2 dapat dilihat bahwa siswa menggambar grafik fungsi $p(x)$. Grafik fungsi $p(x)$ terdiri dari 3 grafik penyusun. Dapat dilihat pada interval $3<x<4$ tidak memiliki grafik. Terdapat indikasi bahwa siswa masih belum paham dengan maksud dari soal bahwa untuk $1 \leq x<4, f(x)=2$. Selain itu, terdapat indikasi bahwa siswa hanya melibatkan bilangan bulat sebagai domain dalam menggambar grafik fungsi. Siswa tidak memperhatikan bahwa ketika $x=3,99$, nilai $f(x)=2$. Gambar 3 memperlihatkan contoh tulisan siswa yang menunjukkan bahwa pemahaman tentang simbol limit masih kurang.

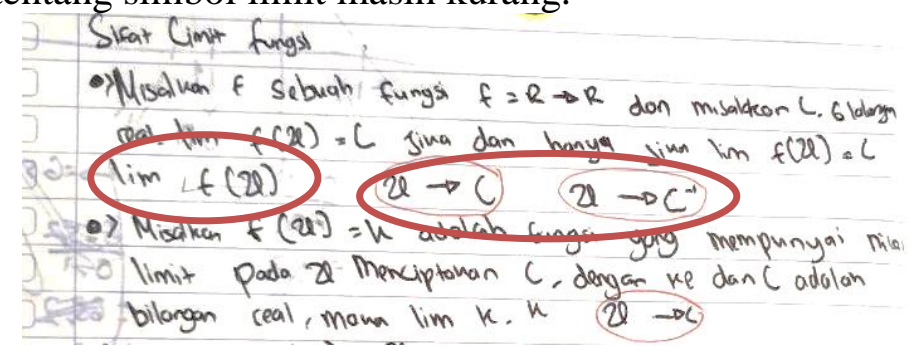

Gambar 3. Pemahaman Siswa tentang Penulisan Simbol Limit Fungsi

Pada Gambar 3 terlihat bahwa siswa hanya menyalin dari buku tanpa memperhatikan penulisan yang benar. Terdapat indikasi bahwa siswa masih belum memiliki skema bahwa simbol limit $x \rightarrow c$ dari $f(x)$ adalah $\lim _{x \rightarrow c} f(x)$. Berdasarkan tiga pekerjaan siswa tersebut, pemahaman matematis perlu ditingkatkan agar siswa dapat belajar matematika dengan baik.

Salah satu model pembelajaran yang dapat diterapkan untuk meningkatkan pemahaman matematis siswa adalah model penemuan terbimbing. Eggen (2012: 177) menyebutkan bahwa dalam model ini siswa secara aktif dilibatkan dalam pembelajaran, guru memberikan contoh dan memandu siswa untuk memahami materi. Pembelajaran dengan model penemuan terbimbing dapat membuat pembelajaran lebih bermakna sehingga materi yang dipelajari oleh siswa dapat bertahan dalam memori jangka panjang. Beberapa penelitian menggunakan model penemuan terbimbing sebagai topik. Mawaddah \& Maryanti (2016) dalam penelitiannya berhasil meningkatkan pemahaman konsep matematis dengan menerapkan model penemuan terbimbing. Muhammad \& Karso (2018) juga melakukan penelitian serupa dengan subjek mahasiswa. Hasil penelitian ini menunjukkan pemahaman konsep matematis mahasiswa meningkat dengan menerapkan model penemuan terbimbing dengan ditunjukkan hasil tes siklus baik dan respon mahasiswa menunjukkan respon positif. Murnaka \& Dewi (2018) juga melakukan penelitian serupa namun membandingkan hasilnya dengan pembelajaran konvensional dan menemukan bahwa siswa yang menggunakan model penemuan terbimbing mengalami peningkatan pemahaman matematis dibandingkan dengan siswa yang menggunakan model pembelajaran konvensional. Ulya, Yuwono, \& Qohar (2017) dalam penelitiannya menemukan adanya peningkatan kemampuan penalaran matematis dengan menerapkan model penemuan terbimbing. Dari hasil-hasil penelitian tersebut dapat diketahui bahwa untuk meningkatkan pemahaman matematis siswa bisa menggunakan model penemuan terbimbing.

Kelebihan-kelebihan model penemuan terbimbing terlihat dari hasil beberapa penelitian. Yurniwati \& Hanum (2017) menemukan bahwa hasil belajar siswa dapat ditingkatkan menggunakan model penemuan terbimbing. Selain itu, Simamora, 
Saragih, \& Siregar (2019) serta Amiyani \& Widjajanti (2018) menunjukkan bahwa model penemuan terbimbing dapat meningkatkan kemampuan matematis siswa.

Berdasarkan uraian tersebut, peneliti melakukan penelitian tindakan kelas dengan menerapkan pembelajaran model penemuan terbimbing untuk meningkatkan pemahaman matematis siswa.

\section{METODE}

Penelitian ini termasuk penelitian tindakan kelas dengan menggunakan pendekatan deskriptif kualitatif. Penelitian ini dilaksanakan di SMA Negeri 5 Malang pada tahun pelajaran 2018/2019. Subyek penelitian ini adalah siswa kelas XI MIPA F4 yang berjumlah 34 siswa. Penentuan subyek pada kelas tersebut didasarkan pada saat observasi terdapat masalah kurangnya pemahaman siswa pada pelajaran matematika.

Teknik pengumpulan data dalam penelitian ini meliputi observasi, dokumentasi dan tes pemahaman matematis siswa. Data yang dianalisis dalam penelitian ini adalah 1) keterlaksanaan pembelajaran dengan model pembelajaran penemuan terbimbing berdasarkan aktivitas guru, 2) aktivitas peserta didik, dan 3) tes pemahaman matematis siswa di setiap akhir siklus. Data hasil penelitian yang berupa data kuantitatif akan dianalisis menggunakan statistik deskriptif, sedangkan data kualitatif akan dijelaskan secara deskriptif.

\section{HASIL}

Penelitian ini dilakukan dalam 2 siklus. Hal ini disebabkan karena hasil belajar pada siklus I belum mencapai tingkat keberhasilan yang direncanakan peneliti. Hasil belajar yang belum memenuhi indikator keberhasilan disebabkan oleh beberapa tindakan pada siklus I yang belum berjalan maksimal, sehingga diperlukan perbaikan di siklus II. Setiap siklus terdiri dari 4 pertemuan yang terdiri atas 3 pertemuan untuk kegiatan pembelajaran dan 1 pertemuan untuk tes akhir siklus untuk melihat pemahaman matematis siswa. Langkah-langkah pembelajaran model penemuan terbimbing yang dapat meningkatkan pemahaman matematis siswa Kelas XI F4 SMA Negeri 5 Malang terdiri dari pendahuluan, inti dan penutup.

Pada kegiatan pendahuluan, peneliti membuka pembelajaran dengan salam lalu memotivasi siswa dengan memaparkan manfaat dari materi yang akan dipelajari dengan memberikan contoh penggunaan materi dalam menyelesaikan masalah, menyampaikan tujuan pembelajaran dan menginformasikan kepada siswa tentang model penemuan terbimbing. Pada kegiatan inti dilakukan tahapan model penemuan terbimbing yaitu (1) Pengenalan dan Review, yaitu tahapan guru mengingatkan kembali tentang materi prasyarat. Selain itu, guru juga memberikan motivasi dengan menyampaikan manfaat materi yang akan dipelajari dalam menyelesaikan masalah; (2) terbuka (Open Ended), yaitu tahapan guru membagi siswa ke dalam delapan kelompok heterogen, kemudian guru memberikan permasalahan kepada siswa yang diselesaikan secara berkelompok dengan membagikan LKS; (3) konvergen yaitu tahapan guru memberikan kesempatan ke siswa untuk mendiskusikan penyelesaian dari permasalahan yang diberikan di LKS; (4) penutup yaitu tahapan guru bersama siswa menyimpulkan materi yang telah dipelajari dan merefleksi kegiatan pembelajaran dengan bertanya materi yang belum dikuasai siswa; dan (5) penerapan yaitu tahapan guru meminta siswa untuk 
menyelesaikan masalah yang berkaitan dengan materi yang telah dipelajari menggunakan konsep yang telah ditemukan. Pada kegiatan ini guru memberikan kuis untuk melihat pemahaman matematis siswa setelah mengikuti kegiatan pembelajaran. Kegiatan penutup dilakukan dengan melakukan pemantapan konsep dari materi yang sudah dipelajari dan mengingatkan entang topik yang akan dipelajari selanjutnya.

Selama proses pembelajaran siklus I dan siklus II berlangsung, dilakukan pengambilaan data tentang keterlaksanaan pembelajaran dengan model penemuan terbimbing. Adapun Hasil penelitian yang telah dilakukan dalam dua siklus dapat dirangkum dalam tabel sebagai berikut:

Tabel 1. Hasil Tindakan Siklus I dan Siklus II

\begin{tabular}{|c|c|c|c|}
\hline \multirow{2}{*}{ Yang Diamati } & \multicolumn{2}{|c|}{ Hasil } & \multirow{2}{*}{ Keterangan } \\
\hline & Siklus I & Siklus II & \\
\hline $\begin{array}{l}\text { Skor Hasil Observasi } \\
\text { Kegiatan Guru }\end{array}$ & 80.96 & 84.81 & $\begin{array}{l}\text { Baik } \\
\text { (Tercapai/Meningkat) }\end{array}$ \\
\hline $\begin{array}{l}\text { Skor Hasil Observasi } \\
\text { Aktifitas Siswa }\end{array}$ & 81.51 & 83.73 & $\begin{array}{l}\text { Baik (Tercapai/ } \\
\text { Meningkat) }\end{array}$ \\
\hline $\begin{array}{l}\text { Rata-rata Hasil Tes } \\
\text { Siswa }\end{array}$ & 70.1 & 85.54 & $\begin{array}{l}\text { Baik (Tercapai/ } \\
\text { Meningkat) }\end{array}$ \\
\hline
\end{tabular}

\section{PEMBAHASAN}

Berdasarkan Tabel 1 dapat dilihat bahwa penelitian ini dari siklus I untuk skor hasil observasi kegiatan guru adalah 80.96 dan pada siklus II adalah 84.81. Kedua siklus menunjukan kriteria baik dan dari siklus I ke siklus II meningkat. Skor hasil observasi aktivitas siswa pada siklus I adalah 81.51 dan pada siklus II adalah 83.73. Kedua siklus menunjukan kriteria baik dan dari siklus I ke siklus II meningkat. Rata-rata hasil tes siswa pada siklus I yaitu 70.1 dan berada pada kategori baik tetapi belum mencapai KKM (kurang dari KKM yaitu 83) sehingga tidak tercapai. Pada siklus II berdasarkan hasil refleksi untuk kendala pada siklus I dan perbaikan pada siklus II sehingga rata-rata hasil tes dari siklus II adalah 85.54 dan ada pada kategori baik serta melebihi KKM. Rata-rata hasil tes dari siklus I ke siklus II juga mengalami peningkatan sehingga penelitian ini bisa dikatakan berhasil.

Pada penelitian ini, siswa mempelajari materi tentang turunan fungsi. Pada siklus I pertemuan pertama, siswa mempelajari sub topik konsep turunan, pada pertemuan kedua mempelajari sub topik sifat-sifat turunan meliputi meliputi turunan fungsi konstan, turunan fungsi identitas, turunan penjumlahan dan pengurangan dua fungsi dan pada pertemuan ketiga, mempelajari sub topik turunan fungsi meliputi turunan perkalian fungsi dengan konstanta, turunan perkalian fungsi, turunan pembagian fungsi, dan turunan fungsi pangkat. Pada pertemuan 1, siswa dikenalkan dengan konsep turunan kemudian pada pertemuan selanjutnya siswa belajar tentang sifat-sifat turunan menggunakan konsep limit. Berikut adalah contoh jawaban siswa yang menunjukkan bahwa siswa tersebut memahami maksud soal dan menjawab dengan benar. 


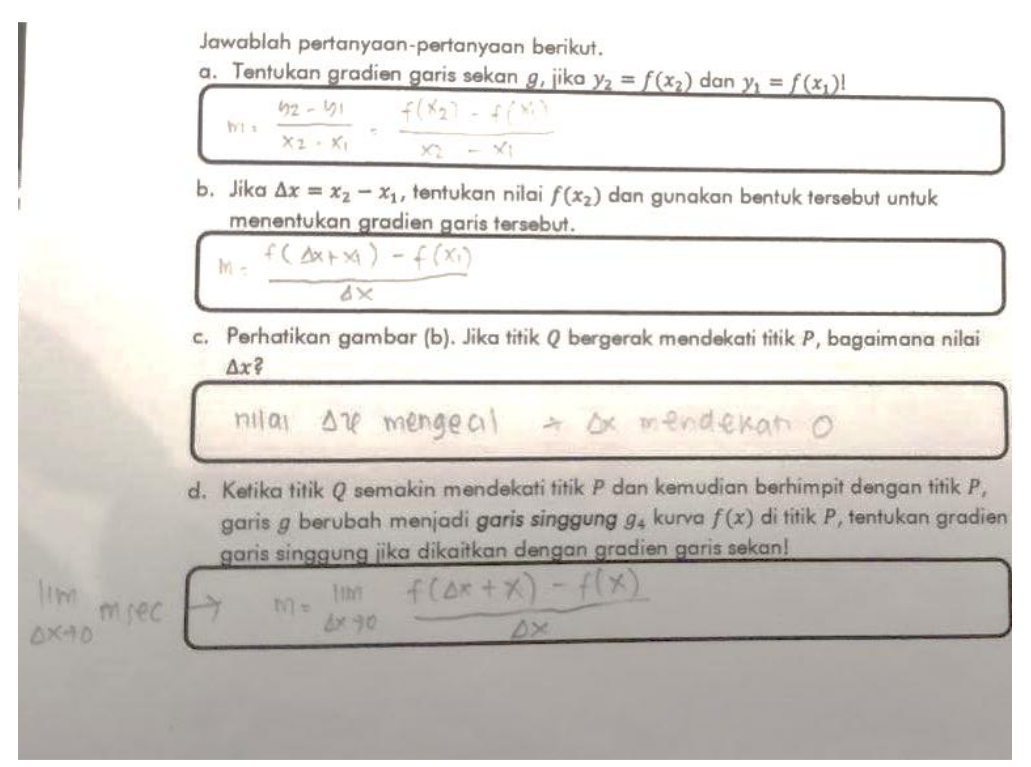

Gambar 4. Contoh Jawaban siswa

Dari gambar 4 dapat dilihat bahwa siswa mengetahui cara menentukan gradien dari suatu garis apabila diketahui 2 titik kemudian dapat mengubah bentuk tersebut sesuai petunjuk pada LKS dan menemukan gradien garis singgung. Hal ini menunjukkan bahwa siswa sudah memiliki skema tentang materi prasyarat yaitu pengetahuan tentang gradien garis dan limit. Hal ini sejalan dengan teori Piaget tentang asimilasi (Slavin, 2006: 32) yaitu siswa menggunakan skema yang sudah ada dalam mempelajari materi yang baru.

Siswa lain memberikan jawaban yang kurang tepat dalam mengomunikasikan ide matematis. Hal ini ditunjukkan pada gambar 5 .

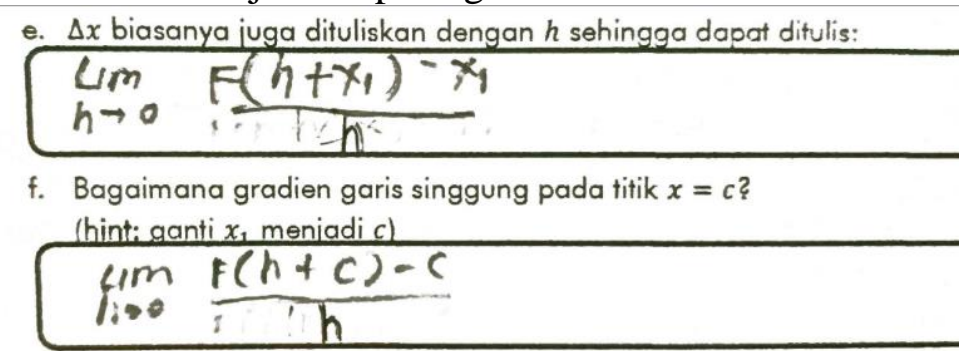

Gambar 5. Jawaban Siswa Dalam Mengomunikasikan Ide

Gambar 5 menunjukkan bahwa siswa belum memahami gradien garis. Terdapat indikasi bahwa skema yang ia miliki tidak dapat membantunya belajar materi baru. Gambar 5 menunjukkan bahwa siswa kurang tepat dengan menuliskan $\frac{f\left(h+x_{1}\right)-x_{1}}{h}$ yang seharusnya ditulis $\frac{f\left(h+x_{1}\right)-x_{1}}{h}$.

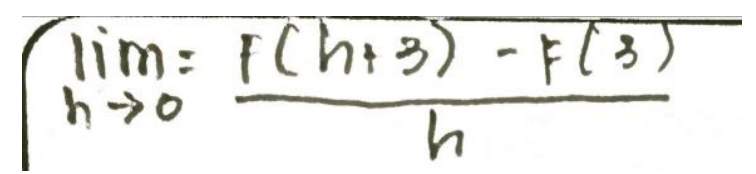

Gambar 6. Penulisan Siswa yang Kurang Tepat

Gambar 6 menunjukkan jawaban siswa dalam belajar konsep turunan. Terlihat bahwa siswa menuliskan tanda sama dengan diantara simbol limit dan

288 BRILIANT: Jurnal Riset dan Konseptual Volume 5 Nomor 2, Mei 2020 
gradien garis. Terdapat indikasi bahwa siswa tidak memahami makna tanda sama dengan. Hal ini juga ditemukan oleh Powell (2015) bahwa salah satu faktor penghambat siswa dalam belajar adalah ketidakpahaman siswa tentang simbol.

Sedangkan pada siklus II pertemuan pertama, peserta didik mempelajari sub topik kemonotonan fungsi, nilai maksimum dan nilai minimum. Dan pada pertemuan kedua, peserta didik mempelajari sub topik persamaan garis singgung dan persamaan garis normal dan pada pertemuan ketiga, mempelajari sub topik penerapan turunan fungsi dalam kehidupan sehari-hari. Berikut adalah contoh jawaban siswa dalam menyelesaikan tes akhir siklus II.

1. Suatu pekerjaan dapat diselesaikan dalam $x$ hari dengan biaya $\left(4 x-16+\frac{2000}{x}\right)$ ribu per hari. Biaya minimum untuk menyelesaikan pekerjaan ini adalah ...

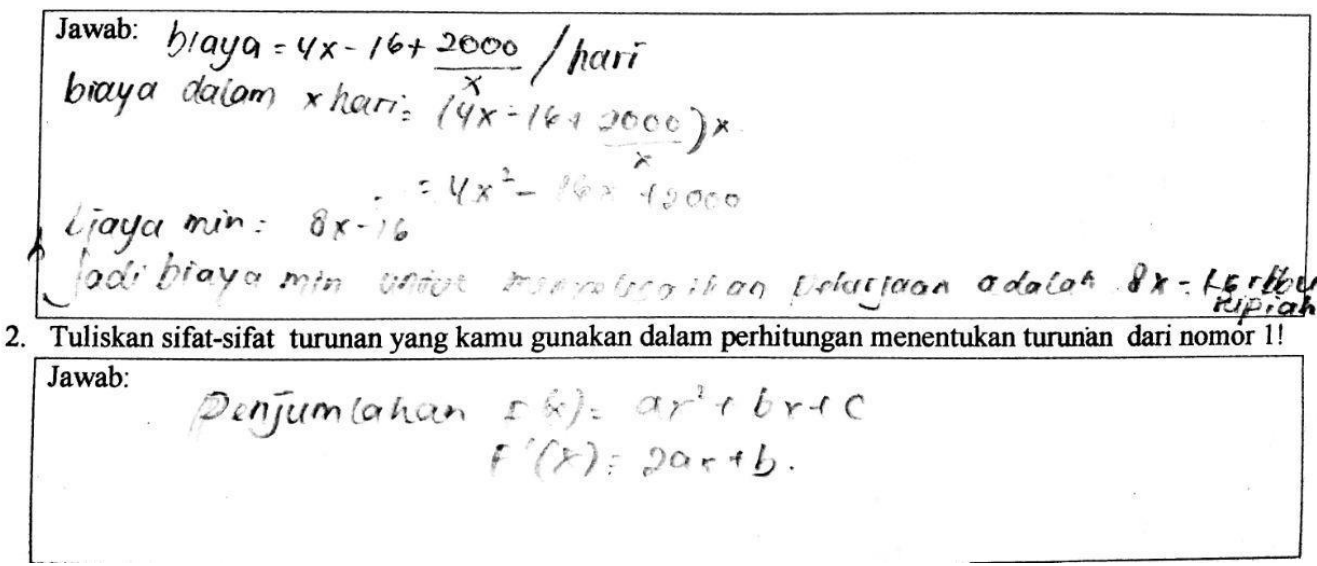

Gambar 7. Jawaban Siswa dalam Tes Akhir Siklus 2

Dari Gambar 7 dapat dilihat bahwa siswa dapat menentukan biaya dalam $x$ hari kemudian menggunakan konsep turunan untuk menentukan biaya minimum dengan syarat turunan dari fungsi biaya sama dengan 0 . Hal ini menunjukkan bahwa siswa telah memiliki skema tentang syarat nilai optimum dalam suatu permasalahan.

\section{KESIMPULAN}

Berdasarkan hasil penelitian dan pembahasan yang telah diuraikan, dapat diperoleh kesimpulan bahwa penerapan model penemuan terbimbing dapat meningkatkan pemahaman matematis siswa pada materi turunan. Hasil dari pemahaman matematis siswa mengalami peningkatan dari rata-rata hasil tes pada siklus I yaitu 70.1 berkriteria baik tetapi belum mencapai KKM menjadi 85.54 dengan kriteria baik dan mencapai KKM pada siklus II. Hasil penelitian lainnya adalah proses peningkatan pemahaman matematis siswa ditandai dengan meningkatnya hasil komunikasi matematis tulis.

\section{SARAN}

Dari hasil penelitian mengenai penerapan model penemuan terbimbing di kelas XI MIPA F4 SMA Negeri 5 Malang, maka saran yang dapat peneliti sampaikan yaitu: (1) terkait tahapan Pengenalan dan Review, guru disarankan lebih membiasakan pengetahuan prasyarat untuk materi yang akan diajarkan supaya siswa bisa memprediksi apa yang akan dipelajari. Selain itu guru harus memberikan instruksi yang jelas dan komunikatif terkait informasi pada LKS, (2) terkait tahapan Konvergen, guru disarankan lebih memberi scaffolding kepada siswa supaya siswa 
lebih aktif dalam berdiskusi dan dapat membangun pengetahuannya sendiri dan (3) penelitian ini hanya terbatas pada topik turunan fungsi dan aplikasi turunan fungsi, peneliti selanjutnya dapat melakukan penelitian lanjutan untuk topik-topik matematika lainya.

\section{DAFTAR RUJUKAN}

Amiyani, R., \& Widjajanti, J. B. 2018. The Excellence of Guided Discovery Learning on Mathematical Knowledge-Based, Skill-Based, and Attitude. IOP Conf. Series: Journal of Physics: Conf. Series 1097. DOI :10.1088/17426596/1097/1/012145.

Anderson, L.W.\& Krathwohl, D.R. (2001). A Taxonomy for Learning, Teaching and Assessing. New York: Addison Wesley Longman.

Eggen, P. \& Kauchak, D. 2016. Educational Psycology: Windows on Classrooms. $10^{\text {th }}$. Upper Saddle River, NJ: Pearson.

Even, R.,\& Tirosh, D.(2002). Teacher Knowledge and Understanding of Students'Mathematical Learning. Dalam L.D. English (Eds.) Handbook of International Research in Mathematics Education (pp 219-240). National Council of Teachers of Mathematics. New Jersey: Lawrence Erlbaum Associates.

Kilpatrick, J., Swafford, J., \& Findell, B. 2001. Adding It Up: Helping Children Learn Mathematics. Editor Killpatrick, J., Swafford, J., \& Findell, B. Washington DC: National Academy Press.

Mawaddah, S. \& Maryanti, R. 2016. Kemampuan Pemahaman Konsep Matematis Siswa SMP dalam Pembelajaran Menggunakan Model Penemuan Terbimbing (Discovery Learning). Edu-Mat, 4(1). 76-85.

Minarni, A., Napitupulu, E.E., \& Husein, R. 2016. Mathematical understanding and representation ability of public junior high school in north sumatra. Journal on Mathematics Education, 7 (1), 43-56.

Muhammad, G. M. \& Karso. 2018. Penerapan Model Guided Discovery Learning untuk Meningkatkan Pemahaman Konsep Matematis Mahasiswa. Jurnal Eksakta Pendidikan, 2(2): 108-115.

Murnaka, N. P. \& Dewi S. R. 2018. Penerapan Metode Pembelajaran Guided Inquiry untuk Meningkatkan Kemampuan Pemahaman Konsep Matematis. Journal of Medives: Journal of Mathematics Education IKIP Veteran Semarang, 2(2): 163-171.

Simamora, R. E. Saragih, S., \& Siregar, H. 2019. Improving Students' Mathematical Problem Solving Ability and Self-Efficacy through Guided Discovery Learning in Local Culture Context. International Electronic Journal Of Mathematics Education, 14(1): 61-72.

Powell, S. R. 2015. The Influence of Symbols and Equations on Understanding Mathematical Equivalence. Intervention in School and Clinic, 50(5): 266272. DOI: $10.1177 / 1053451214560891$

Skemp, R. R. (1976) Relational Understanding and Instrumental Understanding. Mathematics Teaching, 77, 20-26.

Slavin, R. E. 2006. Educational Psychology: Theory and Practice Eighth Edition. Boston: Pearson.

Ulya, I., Yuwono, I., \& Qohar, A. 2017. Pengembangan Perangkat Pembelajaran Bercirikan Penemuan Terbimbing untuk Meningkatkan Kemampuan 
Penalaran Matematis Siswa Pada Materi Barisan Aritmetika dan Geometri Kelas X. Jurnal Kajian Pembelajaran Matematika, 1(1): 17-24.

Yurniwati, \& Hanum, L. 2017. Improving Mathematics Achievement Of Indonesian 5th Grade Students Through Guided Discovery Learning. Journal on Mathematics Education, 8(1): 77-84. 